v súčasnom období určite našla svojho adresáta. Učebnicu považujeme za hodnotné dielo, ktoré predstavuje pozitívny vklad do problematiky výučby cudzích jazykov.

Dúfajme, že v blízkej budúcnosti nás autor poteší vydaním pokračovania danej učebnice pre mierne pokročilý stupeň ovládania ruského jazyka $\left(\mathrm{B}_{1}-\mathrm{B}_{2}\right)$.

fán Gallo

https://doi.org/10.5817/OS2018-4-7

\title{
Новое учебное пособие по морфологии русского языка
}

АРХАНГЕЛЬСКАЯ, А., СЛОВАК,В.: Морфология современного русского языка в сопоставлении с чешским. 1-ое издание. Оломоуц: Издательство Университета им. Ф. Палацкого, 2017. 194 с. ISBN 978-80-244-5249-4.

К началу XXI века резко ускорились изменения в русском языке. Существенные изменения произошли в фонетике и произношении, морфологии и синтаксисе, словообразовании и лексике, так как язык реагирует на все изменения в жизни его носителей. Эти изменения, касающиеся морфологии современного русского языка, освещены в рецензируемом учебном пособии. Оно предназначено для студентов филологических специальностей университетов Чешской Республики, изучающих русский язык как свою специальность. Подготовка и издание настоящего учебного пособия было осуществлено при целевой финансовой поддержке Министерства образования, молодежи и спорта Чешской Республики и Фондом развития Университета им. Ф. Палацкого проекта Vytvoření moderní výukové platformy studia ruštiny na FF UP, FRUP_2017_053. Пособие содержит две части - теоретическую и практическую. Теоретическая часть подготовлена доктором филологических наук, профессором кафедры славистики философского факультета Оломоуцкого университета Аллой Архангельской, практическая часть - докторантом той же кафедры славистики Вацлавом Словаком.

Теория морфологии в пособии рассмотрена с учетом русской и чешской грамматической традиции и актуальных исследований последних десятилетий. В ее основе - системный взгляд на природу языка, взаимодействие его подсистем, системные и асистемные проявления. При изложении материала авторы стремились показать многообразие точек зрения на рассматриваемые проблемы, обозначить и сопоставить подходы к определенному морфологическому явлению в русской традиции и чешской русистике. Исходя из текста теоретической части настоящего пособия следует, что в каждом 
отдельном случае предлагалось решение, которое на сегодняшний день считается наиболее распространенным.

Материал, касающийся грамматических классов слов, изложен следующим образом: частеречное значение, система лексико-грамматических разрядов, система морфологических категорий (несловоизменительных и словоизменительных) особенности словоизменения (в случае изменяемых частей речи), особенности словообразования, часть речи в контексте межчастеречных транспозиций (ср., например, с. 64 - субстантивация прилагательных, с. 72 переход числительных в другие части речи, с. 115 - переход деепричастий в другие части речи и др.). В теоретической части учтены факты системного взаимодействия лексико-грамматических разрядов и морфологических категорий классов слов, факты переходности в системе частей речи и проявления синкретизма, проблемы разграничения полнознаменательных и неполнознаменательных слов, связь морфологии с морфемикой и словообразованием, а также проявления динамики морфологической системы русского языка на современном этапе его развития. Кроме морфологической характеристики слов как частей речи рассматриваются также основные синтаксические функции.

Авторы настоящего пособия пытались учесть наиболее существенные отличия морфологических систем русского и чешского языков (касается это, например, раздела, в котором проходятся особенности числовых форм в русском и чешском языках, где можно наблюдать несовпадения между обоими языками, ср.: охотиться на медведя - lovit medvědy, здесь pacmёm берёза - zde rostou brízy × в вьступить в прениях - vystoupit $v$ diskusi, танць в клубе - taneční zábava v klubu), обозначить проблемные места, вызывающие трудности у чешских студентов-русистов (например, широкое употребление в чешском языке форм сравнительной степени прилагательных в элативном значении с целью ограничения признака: в русском языке это значение часто передается лексическими средствами, ср.: mladší žena - довольно молодая женщина, starší pán - пожилой мужчина), учесть особенности подходов к определению языковых фактов в русской и чешской морфологической традиции (ср., например, раздел, посвященный различиям в системе причастий в русском и чешском языках - с. 112-113).

В самостоятельной главе описываются активные процессы в области морфологии современного русского языка новейшего времени. Морфология, как известно, самый устойчивый, глубинный ярус языковой системы. Изменения в ней происходят крайне медленно: накопления новых изменений малозаметны, если наблюдения ведутся в рамках незначительного промежутка времени. Тем не менее морфология живого языка обнаруживает картину постоянной текучести изменчивости отношений внутри системы, 
связанных с процессами, назревающими и назревшими в ней. В настоящей главе напоминаются основные тенденции, обозначившиеся в морфологии современного русского языка: явное нарастание в языке аналитических черт, предпочтение более экономным средствам выражения, при избыточности вариантных форм - стремление к возможной унификации, активное действие закона аналогии при становлении новых форм, явное вхождение в нейтральный литературный фонд морфологических средств и фактов живой разговорной речи. Языковые изменения осуществляются при взаимодействии причин внешнего и внутреннего порядка. Язык и общество неразрывно связаны, но при этом они имеют свои собственные, отдельные законы жизнеобеспечения.

Практическая часть учебного пособия представляет собой систему упражнений по каждому из изучаемых разделов морфологического изучения о слове, схемы и образцы морфемного и морфологического разбора каждой из частей речи. Система упражнений скоординирована с теоретическими положениями пособия. Упражнения предназначены для работы на семинарских занятиях. Их цель - сформировать у студентов устойчивые умения и навыки системного порядка и применять на практике проходимые морфологические явления, мотивировать учащихся к самостоятельной работе. Практические задания сориентированы на чешского студента-русиста: в них, между прочим, учтены случаи межъязыковой интерференции, вопросы, которые воспринимаются и усваиваются сложнее. По нашему мнению, полезно было бы в каждый тематический раздел упражнений включить упражнение, которое содержало бы перевод чешских конструкций на русский язык (исключение представляет раздел, посвященный союзам); оно содействовало бы повторению и закреплению проходимого материала в сопоставлении с ситуацией в чешском языке. В разделе, в котором упражнения служат для повторения и закрепления теоретических изложений, касающихся деепричастных оборотов, было бы очень неплохо привести упражнение, в котором учащиеся переводили бы русские предложения с деепричастными оборотами на чешский язык; из многолетнего опыта можно сказать, что перевод таких конструкций на чешский язык нередко представляет для чешских студентов затруднения. В разделах, отданным союзам и предлогам, могли бы быть также упражнения, при помощи которых студенты научились бы различать эти части речи с точки зрения их структуры, в случае предлогов также с точки зрения их происхождения. Больше упражнений можно было бы поместить в раздел, в котором студенты должны практически ознакомиться с формами глагольных категорий; на пользу пришли бы и такие задания, в которых можно было бы поупражняться в образовании форм настоящего и прошедшего времени (случайно форм условного наклонения), а также и форм повелительного наклонения. 
В конце учебного пособия включен список использованной и рекомендованной литературы, специальных словарей грамматического типа и справочников, опубликованных в России и Чешской Республике. Он составлен авторами с учетом авторитетных источников предыдущих лет и новейших работ по морфологии русского языка. Авторы настоящего пособия убеждены, что список источников, опирающийся на самые современные поможет учащимся в учебной деятельности сориентироваться в новейших тенденциях в области современного русского языка.

Алеш Бранднер

https://doi.org/10.5817/OS2018-4-8

\section{A New Book on Style of Czech Scholarly Texts}

SCHACHERL, M.: Some Tendencies in Contemporary Scientific Text. České Budějovice: Pedagogická fakulta Jihočeské univerzity, 2018, 212 p., ISBN 978-80-7394-428-5.

The book Some Tendencies in Contemporary Scientific Text by M. Schacherl provides a thorough empirical analysis of various kinds of texts from practically all fields of science, carefully examining selected aspects of their style. Methodologically, this work is based on the functional approach of the Prague School and its successors, stylistics being one of the disciplines in which this approach is still very influential in the context of present-day Czech. However, in this book only one sphere of communication is dealt with, namely the sphere of science in general and within this sphere the types of texts often referred to as theoretical (as distinct e.g. from materials focused on popularizing science, on its practical aspects etc.).

This dominant topic corresponds both with the choice of source texts (their complete list is available in the section dealing with bibliography) and with the selection of the individual investigated aspects, such as the tendency towards using international vs. Czech terminology, some syntactic tendencies, supported also by quantitative data, expressing similarity, using idioms and phrases or expressivity indicated e.g. by the use of quotes. As mentioned above, the work covers a wide range of contemporary theoretical texts, from spheres such as technical sciences, natural sciences, medicine, social sciences and humanities-this wide range provides the possibility to carry out a thorough analysis of interdisciplinary nature, with regard to specific features of the individual disciplines.

The individual partial topics relating to various aspects of means of expression are dealt with very thoroughly, always well supported by the material. Moreover, as 